\title{
Digital Capability and Innovation Strategy to Develop the Performance and Competitive Advantages of Fashion Smes in Jakarta, Indonesia
}

\author{
Erwin Permana*, Bambang Poerwoko, Sri Widyastuti, Widarto Rachbini \\ Sekolah PascaSarjana Universitas Pancasila, Jl. Borobudur No.7, RT.9/RW.2, Pegangsaan, Menteng, Kota \\ Jakarta Pusat, Daerah KhususIbukota Jakarta 10320
}

*Corresponding Author: Erwin Permana, Sekolah PascaSarjana Universitas Pancasila, Jl. Borobudur No.7, RT.9/RW.2, Pegangsaan, Menteng, Kota Jakarta Pusat, Daerah KhususIbukota Jakarta 10320

\begin{abstract}
This research was conducted to: 1) test the impact of digital capability to the performance; 2) test the digital capability impact to the competitive advantage; 3) test the impact of innovation strategy to the competitive advantage, 4) test the innovation strategy to the performance; and 5) test the impact of competitive advantage to the performance. The research was conducted by using 245 Fashion SMEs in Jakarta. Samples were collected based on the SMEs that have utilized the digitack technology in their business activities. Data were analyzed by using Structural Equation Model (SEM) with Partial Least Square (PLS). The result shows that digital capability has some impacts to competitive advantages and the competitive advantages have impacts to the performance. However, digital capability did not have any direct impacts to performance. Innovation strategy has the impacts to the competitive advantages and the performance of the SMEs. It could be stated that digital capability could not directly impact the performance of the SMEs in Indonesia without having the mediation variable by improving the competitive advantages. But, innovation strategy could directly convert to the competitive advantage or the performance of the SMEs.
\end{abstract}

Keywords: Digital Capability, innovation strategy, competitive advantages, performance

\section{INTRODUCTION}

Small and Medium Entreprises (SMEs) is a very important business model that have very important role to stabilize the Indonesian economi. SMEs offered the huge business opportunities that would give the positive impacts to the employments, contribute to the gross domestic product and the distribution of the development result (Sudaryanto, et al., 2014). Referring to the data of the SME Ministry, there are 57.8 millions SMEs in Indonesia on 2014. According to the World Bank's data, SMEs contribute to the Gross Domestic Product (GDP) up to $60 \%$ and $97 \%$ to the employment of the national workforce.

Fashion and craft are the dominant subsectors of SMEs in term of economic contribution. Both industries have become the locomotive in the national creative industry development. The fashion and craft contribution far overcome the contribution of other small industries, in term of value-added, employment, companies, and the amount of the export (Kemenperin, 2016).

The capability of SMES, in term of facing the global competition, indeed should get the special attention in order to be able to survive to maintain the stability of the economic. The Development strategy of SMEs to survive could be done by improving the competitive advantage and by developing the innovation in order to be able to have more values and to be able to survive in the globalization (Russell \& Millar, 2014).

The good performance of the organization would have certain results that could be used and would be useful to develop the competitive advantage for the company. The competitive advantage should be able to be maintain. This is important considering the more competitive advantage we had, the more competitors paid more attentions to our weaknesses. Therefore, a company should be consistent enough to maintain their competitive advantage (Russell \& Millar, 2014). 
Competitive advantage could also be seen through the customers evalution that could be done by the company through the service facilities that could accept any kinds of complaines and suggesstions for the better service of the company - given freely by the customers. The good management of the strategy would be the key success of the company to be the best, by anticipating the market competition (Tarabieh, et at., 2015).

Digital capability is one of those approaches that wer focused on the improvement of the business organization's competitive advantages (Qosasi, et al., 2019). According to Parida, Oghazi, \& Cedergren (2016), digital capability is a firm's ability to strategically use information and communication technology functions or applications in their business activities, such as use of $e$ mails, website, e-commerce, web conferencing, intranet, extranet and other similar tools". Based on the definition by Parida et al.(2016)above, digital capability is the capability of the company to use the ITC function and application in term of business activities such as usinge-mail, website, ecommerce, web conference, intranet, internet dan other kinds of ITC applications. Therefore, the ITC capability is required so the company would be able to adapt, integrate, reconfigure, and recreate the internal and external competences, so it could reach the competitive advantage in the very volatile business environment(Qosasi, et al., 2019).

The digital media utilization as the company capability in the SMEs in Indonesia has shown the high growth level. Euro monitor International stated that the online selling in Indonesia is higher than in Thailand and Singapore. The Indonesian e-commerce market is believed that it has the chances to grow bigger. This idea was supported by the amount of the citizens and the Gross Domestic Brutto (GDP) level that have been considered as the highest in ASEAN. The Statista International notes that Indonesia's online selling yearly growth rate between 2014-2020 is growing. The data shows that the mobile broadband wireless $(3 \mathrm{G}, \mathrm{LTE} / 4 \mathrm{G})$ is most frequently used for personal online transactions. It would also mean that the development of the mobile phone technology has some impacts to the business dynamic. Tke Ministry of Cooperation and SMEs recorded that there are approximately 3,79 million SMEs have used the digital technology such as e-commerce (DeputiPemasaran Kementerian Koperasi dan UMKM, 2017).

In order to be able to survice, the SMEs should have the high performance and it should have the competitive advantage (Muafi et al, 2014). Furthermore, the reseachers have decided to put their focus on the analysis of the variables that were considered as problems for the SMES. Those variables are digital capability (Qosasi, et al., 2019; Ling, Wei, Klimoski, \& Wu, 2015), innovation strategy(Iturrioz, Aragón, \& Narvaiza, 2015; M. Porter \& Michal E, 2013), competitive advantages (Agha, Alrubaiee, \& Jamhour, 2011; Cakmak \& Tas, 2012; Majeed, 2011) and performance(Tarabieh, S.M.Z.A., Ahmad, Z.A. \& Siron, 2015).

The objectives of this research are: (1) the test the impact of digital capability to performance; (2) to test the impact of digital capability to competitive advantages; (3) to test the impact of innovation strategy to competitive advantages; (4) to test the impact of innovation strategy to performance; and (5) the test the impact of competitive advantage to performance.

\section{LITERATURE REVIEW}

\subsection{Digital Capability}

Digital capability has been considered as something very crucial in order to maintain our growth in the Industry 4.0 era. Therefore, digital capability would be extremely important for SMEs. Through the utilization of the digital facility, micro, small and medium enterprise could enter the global market. Only a matter of a relatively short time, the small companies have grown to be the huge world company. For example, we could name several huge companies such as Amazone, Yahoo and Ebay. Those three companies have taken advantages of the digital technology to develop their businesses into as big as it is now (Şerbu \& Borza, 2014).

Therefore, digital technology has provided a decent support for company operational, effectively and efficiently (Chaiprasit \& Swierczek, 2011; Cyril Eze, Guan Gan Goh, Yih Goh, \& Ling Tan, 2013; Dlodlo \& Dhurup, 2013). Digital technology would also be useful to reduce some costs in the business activities, especially for SMEs in term of allocation and keeping their budgets for other usages (Roostika, R., \& Muafi, 2014). 
The utilization of digital technology to run a business for small companies could give the flexibility in term of production, delivery to customers (faster for software), faster offers send and receive - and cheap as well, and it would be useful to support the fast-paperless transaction. Digital technology relates to the way of improving communication, and process or gain information, fast and effective (Barba-Sánchez, 2007; Lyver \& Lu, 2018; M. Porter \& Michal E, 2013). Based on the paper of JISC (2014), Building Digital Capabilities Project 2014-16, there are six basic elements of digital capability. Those elements are ICT proficiency, Critical Use, Creative Product, Participating, Learning, Self-actualising.

\subsection{Innovation Strategy}

There are literatures that could explain why strategy has the impact to stimulate innovation. The mechanism would depend on the applied strategy approach. Strategy often thought as the action to create a direction for the organization by mapping the operational of the company, focusing their effort by coordination promotion, by giving the easy way to know the organization, and by giving the consistency and reducing ambiguity (Iturrioz et al., 2015; Robert Nowacki, 2012).

Innovation strategy is the structural support to have innovation. The development of the innovation strategy would improve the capability of the company's management to have company's innovation (Chen \& Nadkarni, 2017). Innovation refers to the tendency of the companies to do and support the new ideas, newness, experimentation and creative process that could have a new product, service and technology process as product (Covin \& Lumpkin, 2011; Kuratko, 2010).

Based on the exporation of the earlier researches about the innovation dimentions, this research chose the definition of innovation strategy as the concept to make several other dimentions, which are the analysis, aggressiveness, futuristic, proactive, risk taker (Dincer, Dincer, \& Yilmaz, 2015)and commitment (Barney \& Hansen, 1994). The researchers have added one more dimension, the literation. This was done considering that innovation has the very close relation to the organization learning. (Baker \& Sinkula, 2009)has conceptualized and operated the learning orientation that consists of the commitment of learning, collective vision, and the open mind (Baker \& Sinkula, 2009). Thus, the literation perfects the understanding of the innovation strategy. The literation dimension is defined as the capabity to read the business phenomena. Therefore, we got seven innovation strategy dimensions in total; the analysis, aggressiveness, futuristic, proactive, risk taker, commitment, and literation.

All built dimensions were directed to the combination of manufacture innovation that have been done by the company, and the product itself. The innovation strategy was not being related to the digital information technology. This was done to avoid the possible construct replication of the research instruments. The innovation dimension as directed to the three innovation types: product, process and organization (McAdam, Moffett, Hazlett, \& Shevlin, 2010).

\subsection{Competitive Advantage}

Competitive advantage is an advantage to the other companies (competitors) which was gained by offering the bigger or higher customer value, either by lowering the price or giving the bigger benefits for the customers (M. E. Porter, 2008). Earlier, Porter (2001) defined the competitive advantage in three dimensions; cost, differentiation and focus to the competitors that were trying to able to get out of the cown without competitive advantages. Porter showed that differentiation could reduce the cost, compared to the competitors. Differentiation is considered as the only possible way to reach the competitive advantage. Normally, it came from the big scale organization that were working on their effiecieny based on their repetitive experiences in the past, in term of lowering the cost. Another way to get the competitive advantage is by making some changes in all aspects that are related to the value from the customers' view, either from the attractive aspects of the products (differentiation) or by developing a campaign that could give the customers the understanding that they could find all they need in the products, with the best qualities and the very competitive prices.

Competitive advantage is a far as an organization was capable to put themselves into the market maintaining position against the competitor. Company would create the competitive advantage through their competitive capability or defined priorities as strategy preferences, or the dimension where the company chose to compete in the targeted market. 
We could find many kinds of competitive priorities were identified in literatures. Moreover, lots of literatures found several steps to get the competitive advantage (Russell \& Millar, 2014).Based on the exploration on the competitive concept, the researchers synthesized several dimensions of competitive advantage which are; differentiation (Tarabieh, S.M.Z.A., Ahmad, Z.A. \& Siron, 2015), latest technical knowledge, brand (SirivanhdanSukkabot, 2014)and uniqueness. Unique is defined as a value that differs a product to others (Daou, Karuranga, \& Su, 2014). SMEs should be able to products some kind sof unique products to have the competitive advantage.

\subsection{Performance}

The superior company performance reflects the company's competitive advantage. The competitive advantage is the capability to win the market competition by using the different capability (or ways) that other players (in the same market) do not have (Roostika, Wahyuningsih, \& Haryono, 2015). The results of some earlier studies showed that the competitive advantage has impacts to the performance of the organization (Agha et al., 2011; Ismail, A. I., Che Rose, R., Abdullah, H., \& Uli, 2010; Majeed, 2011). Therefore, the competitive advantage would be gained if a company could use their resources, including their capability to reach the superior and relatively low cost customer's value.

Company performance is a holistic display of a company of a certain period of time, that is the result of company operational activities of how they could use their certain resources (Das, Paul, \& Swierczek, 2008). It should be measured subjectively to examine the impacts of customer orientation and additional service (Tarabieh, S.M.Z.A., Ahmad, Z.A. \& Siron, 2015). Performance measurement itself is considered as the proses to measure efficiency and effectivity of the actions. Performance measurement is also defined as the activitiy to measure the input, output, and activity level of a process (Gupta \& Nanda, 2015).

(Aliyu, 2016)used the Total Quality Management (TQM) concept to measure the performance of the SMEs. (Douglas \& Judge, 2001)operates the TQM as the uni-dimensional construct. Based on the literature review, the most commonly used critical factors of TQN that have impacts to business performance are: management leadership, training, customer focus, continuous improvement, and management process.

Based on the literature review, this paper proposed the research hypothesis:

$\mathrm{H} 1=$ Digital capability has impact to the company performance

$\mathrm{H} 2=$ Digital capability has impact to the competitive advantage

$\mathrm{H} 3=$ Competitive advantage has impact to the company performance

\section{Methodology}

The objects of this research are the fashion SMEs in several regions of Jabodetabek (Jakarta, Bogor, Depok, Tangerang, and Bekasi), that fulfill these criteria: 1) use the digital technology in their business activities; 2) the business has been operated at least 2 (two) years. We used the Structural Equation Model (SEM) with Partial Least Square (PLS) to analyse the result.We used 200 SMEs as the samples. As what stated by (Suwarno, 2002), the number of samples that is considered could give the stable results would be between 100 to 200 respondents. The research was done in Februari to March 2019.In orderto have the focus and clear analyses, we have designed some research instruments based on research variable and dimensions.

Table1: Research Instrument

\begin{tabular}{|c|c|c|}
\hline Variable & Dimension / Sub Variable & Indicator \\
\hline \multirow[t]{2}{*}{ ICT Capability } & ICT proficiency & $\begin{array}{l}\text { 1. Use digital media to market the product } \\
\text { 2. Follow the internet technology development to market the } \\
\text { product } \\
\text { 3. Maintain and update online media to market product }\end{array}$ \\
\hline & Critical Use & $\begin{array}{l}\text { 1. Follow the latest information on product development in } \\
\text { internet } \\
\text { 2. Use all kinds of content digital as photo, video to market } \\
\text { product } \\
\text { 3. Have the data of customers and potential customers }\end{array}$ \\
\hline
\end{tabular}


Digital Capability and Innovation Strategy to Develop the Performance and Competitive Advantages of Fashion Smes in Jakarta, Indonesia

\begin{tabular}{|c|c|c|}
\hline Variable & Dimension / Sub Variable & Indicator \\
\hline & Creative Product & $\begin{array}{l}\text { 1. Enrich the marketing site with product-related writings to } \\
\text { improve rating } \\
\text { 2. Understand the customers' demand through digital media } \\
\text { 3. Enlarge the usage of digital technology }\end{array}$ \\
\hline & Participating & $\begin{array}{l}\text { 1. Participate in Digital Learning } \\
\text { 2. Colaborate with other parties in product marketing } \\
\text { 3. Have ethical behavior in digital communication }\end{array}$ \\
\hline & Learning & $\begin{array}{l}\text { 1. Understand the interlocutors in the online media } \\
\text { 2. Use digital tool (personal or organization) to learn } \\
\text { 3. Have attention and motivation to learn in digital setting }\end{array}$ \\
\hline & Self-actualising & $\begin{array}{l}\text { 1. Perfect balancing between digital interaction and actual } \\
\text { interaction. } \\
\text { 2. Being secure and responsible in digital environment } \\
\text { 3. Develop and manage digital reputation (persona or } \\
\text { organization) }\end{array}$ \\
\hline \multirow[t]{7}{*}{$\begin{array}{l}\text { Innovation } \\
\text { Strategy }\end{array}$} & Analysis & $\begin{array}{l}\text { 1. Analyze for new product periodically } \\
\text { 2. Analyze for new production method periodically } \\
\text { 3. Analyze for business activities enhancement to support } \\
\text { productivity, periodically }\end{array}$ \\
\hline & Aggressiveness & $\begin{array}{l}\text { 1. Product could adjust customers' demand } \\
\text { 2. Use the latest production method } \\
\text { 3. Apply the latest management concept }\end{array}$ \\
\hline & Futuristic & $\begin{array}{l}\text { 1. Develop future product } \\
\text { 2. Develop future production method } \\
\text { 3. Develop future organization shape }\end{array}$ \\
\hline & Proaktive & $\begin{array}{l}\text { 1. Independently create the new product } \\
\text { 2. Independently create the new production method } \\
\text { 3. Independently create the more efficient new organization } \\
\text { model }\end{array}$ \\
\hline & Risk Taker & $\begin{array}{l}\text { 1. Did not worry to create and market new product } \\
\text { 2. Did not worry to adopt new production method } \\
\text { 3. Did not worry to change the shape or the organization }\end{array}$ \\
\hline & Commitment & $\begin{array}{l}\text { 1. Keeping the quality before market } \\
\text { 2. Fixing the work facilities to support production } \\
\text { 3. Take care of the organizational culture }\end{array}$ \\
\hline & Literacy & $\begin{array}{l}\text { 1. Search and understand the development of new products } \\
\text { 2. Search and understand tke development of new production } \\
\text { method } \\
\text { 3. Search and understand the latest technology development }\end{array}$ \\
\hline \multirow[t]{4}{*}{$\begin{array}{l}\text { Competitive } \\
\text { Advantage }\end{array}$} & Product Differentiation & $\begin{array}{l}\text { 1. Sell various sizes of products } \\
\text { 2. Sell various categories of products } \\
\text { 3. Sell various quality types of products }\end{array}$ \\
\hline & Latest technical knowledge & $\begin{array}{l}\text { 1. Understand the technical aspects of latest product } \\
\text { 2. Understand the latest marketing technique } \\
\text { 3. Understand financial recording }\end{array}$ \\
\hline & Brand & $\begin{array}{l}\text { 1. Use various brands in market } \\
\text { 2. Create own brand }\end{array}$ \\
\hline & Uniqueness & $\begin{array}{l}\text { 1. Have an attractive product to be sell } \\
\text { 2. Offer the different products than the similar ones } \\
\text { 3. Offer the better products than others }\end{array}$ \\
\hline \multirow[t]{3}{*}{$\begin{array}{l}\text { SME } \\
\text { Performance }\end{array}$} & Management Leadership & $\begin{array}{ll}\text { 1. } & \text { Target Plan } \\
\text { 2. } & \text { Team organization } \\
\text { 3. } & \text { Performance Control } \\
\text { 4. } & \text { Staff Performance Evaluation }\end{array}$ \\
\hline & Training & $\begin{array}{l}\text { 1. Join Entrepreneurship Training } \\
\text { 2. Join product marketing training } \\
\text { 3. Join any related trainings }\end{array}$ \\
\hline & Customer Focus & $\begin{array}{l}\text { 1. Repeat orders } \\
\text { 2. Customer RElationship } \\
\text { 3. } \text { Customer input for new product development }\end{array}$ \\
\hline
\end{tabular}


Digital Capability and Innovation Strategy to Develop the Performance and Competitive Advantages of Fashion Smes in Jakarta, Indonesia

\begin{tabular}{|c|c|c|}
\hline Variable & Dimension / Sub Variable & Indicator \\
\hline & & 4. Customer growth from time to time \\
\hline & Continuous Improvement & $\begin{array}{l}\text { 1. Periodical Sales evaluation } \\
\text { 2. Improving business management } \\
\text { 3. } \text { Improving employee relation }\end{array}$ \\
\hline & Strategic Planning & $\begin{array}{l}\text { 1. Have a long term strategic plan } \\
\text { 2. Plan a measured sales target } \\
\text { 3. Plan a measured supplies target }\end{array}$ \\
\hline & Management Process & $\begin{array}{l}\text { 1. Apply and improve SOP } \\
\text { 2. Clear job description application } \\
\text { 3. } \text { Minimize trouble in production and selling process }\end{array}$ \\
\hline
\end{tabular}

Those instruments were measured using the Likert scale, with 5 levels of scale; 5=strongly agree, 4=Agree, 3=Neither agree nor disagree, 2=Disagree, 1=Strongly disagree .

\section{RESUlt AND DisCUSSION}

Female seem to be more dominant than male in the fashion SMEs, as it was shown in the result, female $(61.15 \%)$ compared to make $(22.75 \%)$ of total 200 respondents. Respondents' distributions based on their latest educaton level are divided into 5 (five) categories; high school or below associate's degree 3.04\%, Associate's Degree (D3) sebanyak3.91\%, Bachelor (S1) 90.87\%, Master (S2) $1.74 \%$ dan Doctoral (S3) $0.43 \%$. Based on the statement of the $20^{\text {th }}$ Act of 2008 on SMEs critera, the respondents were diveided into micro business $87.60 \%$, small business $7.44 \%$ and medium business $4.96 \%$.

Here are the analysis by using SEM - PLS. The analysis SEM with PLS was done in three phases; the outer model analysis, inner model analysis, and hypothesis testing. According to (Ghozali, 2011), construct realibility test is measured wit the composite reliability andcronbach's alpha. Construct would be considered as realiable if it has composite reliability above 0,70 and cronbach's alpha above 0,60 . The average variance extracted (AVE) that would be considered enough to measure the validity would be as much as 0,5 .

Table1: Cronbach Alpha, Composite Reliability Dan Average Variance Axtracted

\begin{tabular}{|l|l|l|l|l|l|}
\hline & Cut-off Value & Digit_Capabil & Comp_Advantage & Performance_SME & \multicolumn{1}{|c|}{ Remark } \\
\hline $\begin{array}{l}\text { Cronbach's } \\
\text { Alpha }\end{array}$ & $>0.6$ & 0,823 & 0,823 & 0,819 & $\begin{array}{l}\text { All fashion } \\
\text { SMEs aspects } \\
\text { meet the } \\
\text { standard }\end{array}$ \\
\hline $\begin{array}{l}\text { Composite } \\
\text { Reliability }\end{array}$ & $>0.7$ & 0.763 & 0.840 & 0,819 & \\
\hline $\begin{array}{l}\text { Average } \\
\text { Variance } \\
\begin{array}{l}\text { Extracted } \\
\text { (AVE) }\end{array}\end{array}$ & $>0.5$ & 0.763 & 0,623 & 0,661 & \\
\hline
\end{tabular}

Source: Output SmartPLS 3.0 (2019).

Based on the criteria on table 4.20, the result shows that all outer model criterias were fulfilled, therefore it could be concluded that this research's data have the good validity and realibility. So the research could be proceed to the inner model analysis.

Inner model evaluation could be seen from several indicators that cover: determination coefficient $\left(\mathrm{R}^{2}\right)$; Predictive Relevance $\left(\mathrm{Q}^{2}\right)$; Goodness of Fit Index $(\mathrm{GoF})$.

Here are the calculations of each indicator:

1. Determination Coefficient $\left(\mathrm{R}^{2}\right)$

The value of $\mathrm{R}^{2}$ output software smartPLS 3

Table2: Nilai $R^{2}$

\begin{tabular}{|l|l|l|}
\hline & $R$ Square & $R$ Square Adjusted \\
\hline Digital Capability & 0,768 & 0,737 \\
\hline Competitive Advantage & 0,786 & 0,743 \\
\hline Performance & 0,773 & 0,741 \\
\hline
\end{tabular}

Source: Output smartPLS 3 (2019) 
Referring to(Newsted, 1999), the R Square equal to 0.67 is strong, 0.33 is moderate, and the under 0.19 is weak. Therefore, this reseach model is considered of having the strong relations between analyzed variables. There are two endogen variables; competitive advantage and performance dan one exogen variable. Referring to the value of $r$ square and adjusted $r$ square, it could be stated that there are strong relation between exogen variable, single, or combined.

\section{Predictive Relevance $\left(\mathrm{Q}^{2}\right)$}

To find the value of $\mathrm{Q} 2$, we used the formula:

$\mathrm{Q}^{2}=1-\left(1-\mathrm{R} 1^{2}\right)\left(1-\mathrm{R} 2^{2}\right) \ldots . .\left(1-\mathrm{Rn}^{2}\right)$

$\mathrm{Q}^{2}=1-(1-0,768)(1-0,786)(1-0,773)$

$\mathrm{Q}^{2}=0,989$

Chin in(Newsted, 1999) stated, if the counted value 0.02, the model is considered of having the small prediction capability. If it showed the 0.15 , it means the model has the medium prediction capability. And if the value was 0.35 , the model has the high prediction capability. The calculation of $\mathrm{Q}^{2}$ would have 0.989 . Therefore, the model has the high prediction capability.

\section{Goodness of Fit Index $(\mathrm{GoF})$}

GoF value on SEM with PLS was calculated manually (Tenenhaus \& Esposito, 2005)using this formula:

$\mathrm{GoF}=\sqrt{A V E}^{2} \times \overline{\mathrm{R}^{2}}$

$\mathrm{GoF}=0.4$

According to(Tenenhaus \& Esposito, 2005) and Tenenhaus (2004), the value of GoF is considered as small $=0,1$, GoF medium $=0,25$ and GoFhigh $=0,38$. Based in the calculation of GoF Value, it could be found that this model has the bigger GoF value, so the model represents the real phenomena. The next step is reseach hypothesis test.

In term of hypothesis test, a bootstrapping process has been done inside the SEM PLS to calculate the $\mathrm{T}$-count. If t-coung his higher than t-statistic with the confidence level 95\% (>1.96), the hypotheses is significant. In order to know how significant the impacts between variables of this research, we could see in the loading factor original value of the SmartPLS output. Table 3 would show us the path coefficients of the SmartPLS output.

Table3: Path Coefficients (Mean, STDEV, $t$-Value)

\begin{tabular}{|l|l|l|l|l|l|}
\hline \multicolumn{1}{|c|}{ Hipotesis } & \multicolumn{1}{|c|}{$\begin{array}{c}\text { Original } \\
\text { Sample (O) }\end{array}$} & $\begin{array}{c}\text { Sample Mean } \\
(\mathbf{M})\end{array}$ & $\begin{array}{c}\text { Standard Deviation } \\
(\text { STDEV) }\end{array}$ & $\begin{array}{c}\text { T Statistics } \\
(\mathbf{\text { O/STDEV }})\end{array}$ & P Values \\
\hline $\begin{array}{l}\text { Digital_Capability } \\
>\text { SME Performance }\end{array}$ & 0,154 & 0,156 & 0,106 & 1,461 & 0.144 \\
\hline $\begin{array}{l}\text { Digital_Capability-> } \\
\text { Competitive Advantage }\end{array}$ & 0,438 & 0,465 & 0,075 & 5,822 & 0,000 \\
\hline $\begin{array}{l}\text { Competitive Advantage- } \\
>\text { SME Performance }\end{array}$ & 0,470 & 0,488 & 0,086 & 5,445 & 0,000 \\
\hline
\end{tabular}

Source: Output SmartPLS, 2019

Based on the table 3. output path coefficients (Mean, STDEV, t-value), two of the hypotheses have tvalue over 1,96, and one hypothesis has t-value under 1,96. It means, from the three hypotheses, two hypotheses were proven to have positive and significant impacts, and the other one was not. Summing up the hypotheses test result, we could see it in the table 4.

Table4: Result of Hypotheses Test

\begin{tabular}{|l|l|l|}
\hline No & \multicolumn{1}{|c|}{ Hypoteses } & \multicolumn{1}{|c|}{ Result } \\
\hline $\mathrm{H}_{1}$ & Digital capability has impact to the company performance & Rejected \\
\hline $\mathrm{H}_{2}$ & Digital capabilityhas impact to the competitive advantage & Accepted \\
\hline $\mathrm{H}_{3}$ & Competitive advantage has impact to the company performance & Accepted \\
\hline
\end{tabular}

Source: Processes by researchers (2019) 
Based on the running result, the digital capability variable turned out to have non-signigiant impact to the competitive advantage variabl. It is different with the previous research's result by (Rai, Patnayakuni, \& Seth, 2006)that showed that IT has positive impact to organization performance. This, however, is acceptable since the focus of this research is the digital capability, not the information technology part.

There are different meanings between ITC capability and the ITC itself.Qosasi \& Permana, (2017)defined ITC Capability as the capability of the business owner to utilize the digital media/information technology to support their business. Information technology itself is a set of technology that is being used by an organization to create, process and spread the information in any possible forms. Therefore, information technology provides the support to the company's operation (Qosasi \& Permana, 2017).

This result however is along side with the OECD publication on 2014 that stated one of the weaknesses of the SMEs is the limitation of capability and aggressiveness of the SMEs owner and workers to improve the business performance by utilizing the digital media. There are several factors that could hold SMEs of using the internet. Those factors are the different type of business process, lack of knowledge - in term of internet operation, lack of internet managerial capability, lact of internet connecton and computers availability, lact of trust and security of intenet, and the high cot of computer maintainance and development.

Based on the running result it was well proven that digital capability variable has significant impacts to the competitive advantage variable. This is similar to the earlier research by (Cakmak \& Tas, 2012). It was stated that diital capability has positive impacts to the competitive advantage. Digital capability impacts the competitive advantage of SMEs, because by the existence of sufficient digital capability the competitive advantage would be improved. Digital capability is the capability of the business owners to utilize the digital media/information technology to support the business. Information technology itself is a set of technology that is being used by an organization to create, process and spread any forms of information. Therefore, information technology provides the company's operation. Information technology is useful to reduce the cost of business activities, especially for SMEs that might need more space in their budget allocation (Roostika, R., \& Muafi, 2014).

It is understandable that digital capability has impact to the competitive advantage but it does not have any impacts to the SMEs performance. According to Clarismary, et al (2015), the ICT proficiency dimension is a dimension that capable to have the direct impact to the company's performance, yet it has the smallest weight, compared to the other dimensions. ICT proficiency is defined as the capability to critically judge the positive impacts/constraints of the ICT approach and application; design and apply the ICT solution to be recovered from such failure and to maintain the target. Self actualizing is defined by the effort to built and maintain the digital profile; develop personal style and value in the digital participation; and arrange the personal material in the digital network. Learning is defined as the capability to identify and participate in the digital learning; and or participate in the digital learning connection learjing process. Participating is defined as the participation in the social, culture and business life by using the digital forum and service.

The competitive advantage variable has the significant impact to the SME performance. The superior organization performance reflects the company's competitive advantage. The competitive advantage is the capability to win the market competition though some different ways that could not be done by competitors (Porter, 1998). Previous results of several researches showed that the competitive advantage really has impacts to the organization performance (Agha et al., 2011; Ismail, A. I., Che Rose, R., Abdullah, H., \& Uli, 2010; Majeed, 2011).

Chibelushi \& Trigg, (2012)stated that the competitive advantage concept should be the attention of the company or organization that produce product and service to maintain the business and its benefits. SMEs business performance is being improved by the SMEs competitive advantage through the profit growth, sales growth and customers growth. According to (Chan, Shaffer, \& Snape, 2004), competitive advantage has positive impacts to the company's performance. Several indicators should be created to measure the profits, including the customers loyality, technology development and product development. Sales growth, customers growth, profit growth and capital growth 
measurements are the indicators of SMEs business performance. This research found two dominant SMEs performance dimensions; the customer focus and the continuous performance.

\section{CONCLUSION, IMPLICATION AND LIMITATION}

This research has proven the impact of digital capability variable to the competitive advantage and performance variables of Fashion SMEs in Jakarta. The result shows that in Indonesia, digital capability does not have any impacts to the SMEs performance. This result is similar as the statement of the OECD publication (2014). Yet, according to the same paper, it was stated that digital capability has significant impact to the performance, in the large scale. There are several factors that might cause the insignificancy of digital capability impact to the SMEs performance. Those factors are the different type of business process, lack of internet usage knowledge management, lack of internet connection and computers availability, lact of trust and security of internet and the large cost of computer development and maintenance.

This research proves that digital capability was formed by creative, critical use, ICT Proficiency, learning, participating, andself actualization. Self actualization is the main dimension. It does not have any impacts to the SMEs performance, but it has impact to the competitive advantage.

This result also proves that competitive advantage has impact to the performance, though the different dimensions, compared to the prior researches. Dimensions that were being proposed in this research are differentiation, brand, knowledge, and uniqueness. This is also confirmed the teori that competitive advantage always improves business performance, even from different dimensions. SMEs performance in this research consists if management leadership, training, customer focus, continuous improvement, and management process. Continuous improvement is the main dimension. This is similar with the aggressive strategy innovation variable. Leadership management and process management are proven as the non-dominant dimensions in the SMEs performance.

SMEs owner should improve their digital capability, mainly the ICT proficiency, so they would be able to operate the bsiness, effectively and efficiently, gain more information, and able to use the ICT to promote the business widely, so it would have the direct impact to the business performance.

Based in those conclusions, this research has implication as the input for the government to develop the SMEs. Those implications are: 10 Create the condussive environment for the digital technology develoment and digital business learning; 2) Always evaluate the grant for the SMEs, especially on how it was being applied, and simplified the funding mechanism for simpler access; 3) In term of innovation stimulation, the government shoud give the attention and credits to the innovation of the SMEs; and 4) Improve the protection for the SMEs from the local, national and international market competition. Letting the SMEs to compete with the giants might have lethal impacts to the SMEs, considering that it could not compete in term of capital, management and human resources, compared to those giants.

\section{REFERENCES}

[1] Achsanul Qosasi, Erna Maulina, Margo Purnomo, Anang Muftiadi, Erwin Permana*, F. F. (2019). THE IMPACT OF INFORMATION AND COMMUNICATION TECHNOLOGY CAPABILITY ON THE COMPETITIVE ADVANTAGE OF SMALL BUSINESSES. International Journal of Technology, 10(1), 167-177.

[2] Agha, S., Alrubaiee, L., \& Jamhour, M. (2011). Effect of Core Competence on Competitive Advantage and Organizational Performance. International Journal of Business and Management, 7(1). https://doi.org/ 10.5539/ijbm.v7n1p192

[3] Aliyu, M. A. (2016). Modelling Total Quality Management Dimensions for Sme. Journal of Education and Social Sciences., 3(1995), 165-169.

[4] Baker, W. E., \& Sinkula, J. M. (2009). Orientation and Entrepreneurial Orientation. Journal of Small Business Management, 47(4), 443-464. https://doi.org/10.1111/j.1540-627X.2009.00278.x

[5] Barba-Sánchez, V. (2007). Drivers, benefits and challenges of ICT adoption by small and medium sized enterprises (SMEs): A literature review. ... and Perspectives in ..., 5(April 2016), 103-114. Retrieved from http://www.academia.edu/download/30924479/PPM_EN_2007_01_Barba-Sanchez.pdf

[6] Barney, J. A., \& Hansen, M. H. (1994). Trustworthiness as a source of competitive advantage. Strategic Management Journal, 15(5), 175-190. https://doi.org/10.5465/APBPP.2002.7519517

[7] Cakmak, P. I., \& Tas, E. (2012). The use of information technology on gaining competitive advantage in Turkish contractor firms. World Applied Sciences Journal, 18(2), 274-285. https://doi.org/10.5829/idosi. wasj.2012.18.02.744 
Digital Capability and Innovation Strategy to Develop the Performance and Competitive Advantages of Fashion Smes in Jakarta, Indonesia

[8] Chaiprasit, S., \& Swierczek, F. W. (2011). Competitiveness, globalization and technology development in Thai firms. Competitiveness Review: An International Business Journal Incorporating Journal of Global Competitiveness, 21(2), 188-204. https://doi.org/10.1108/10595421111117461

[9] Chan, L. L. M., Shaffer, M. A., \& Snape, E. (2004). In search of sustained competitive advantage: the impact of organizational culture, competitive strategy and human resource management practices on firm performance. The International Journal of Human Resource Management, 15(1), 17-35. https://doi.org/10. 1080/0958519032000157320

[10] Chen, J., \& Nadkarni, S. (2017). It's about Time! CEOs' Temporal Dispositions, Temporal Leadership, and Corporate Entrepreneurship. Administrative Science Quarterly, 62(1), 31-66. https://doi.org/10.1177/ 0001839216663504

[11] Chibelushi, C., \& Trigg, D. (2012). Internal self-assessment for ICT SMEs: a way forward. International Journal of Business Performance Management, 13(2), 103. https://doi.org/10.1504/IJBPM.2012.046196

[12] Covin, J. G., \& Lumpkin, G. T. (2011). Entrepreneurial orientation theory and research: Reflections on a needed construct. Entrepreneurship: Theory and Practice, 35(5), 855-872. https://doi.org/10.1111/j.15406520.2011.00482.x

[13] Cyril Eze, U., Guan Gan Goh, G., Yih Goh, C., \& Ling Tan, T. (2013). Perspectives of SMEs on knowledge sharing. Vine, 43(2), 210-236. https://doi.org/10.1108/03055721311329963

[14] Daou, A., Karuranga, E., \& Su, Z. (2014). Towards a better understanding of intellectual capital in Mexican SMEs. Journal of Intellectual Capital, 15(2), 316-332. https://doi.org/10.1108/JIC-08-2013-0092

[15] Das, A., Paul, H., \& Swierczek, F. W. (2008). Developing and validating total quality management (TQM) constructs in the context of Thailand's manufacturing industry. Benchmarking: An International Journal, 15(1), 52-72. https://doi.org/10.1108/14635770810854344

[16] Dincer, F. I., Dincer, M. Z., \& Yilmaz, S. (2015). The Economic Contribution of Turkish Tourism Entrepreneurship on the Development of Tourism Movements in Islamic Countries. Procedia - Social and Behavioral Sciences, 195, 413-422. https://doi.org/10.1016/j.sbspro.2015.06.483

[17] Dlodlo, N., \& Dhurup, M. (2013). Drivers of E-Marketing Adoption among Small and Medium Enterprises (SMEs) and Variations with Age of Business Owners. Mediterranean Journal of Social Sciences, 4(14), 53-66. https://doi.org/10.5901/mjss.2013.v4n14p53

[18] Douglas, T. J., \& Judge, W. Q. (2001). Total Quality Management Implementation and Competitive Advantage: the Role of Structural Control and Exploration. Academy of Management Journal, 44(1), 158169. https://doi.org/10.2307/3069343

[19] Ghozali, I. (2011). “Aplikasi Analisis Multivariate Dengan Program SPSS.” Semarang: Badan Penerbit Universitas Diponegoro.

[20] Gupta, H., \& Nanda, T. (2015). A quantitative analysis of the relationship between drivers of innovativeness and performance of MSMEs. International Journal of Technology, Policy and Management, 15(2), 128. https://doi.org/10.1504/IJTPM.2015.069202

[21] Ismail, A. I., Che Rose, R., Abdullah, H., \& Uli, J. (2010). The Relationship between Organisational Competitive Advantage and Performance Moderated by the Age and Size of Firms. Asian Academy of Management Journal,15(2), 157-173.

[22] Iturrioz, C., Aragón, C., \& Narvaiza, L. (2015). How to foster shared innovation within SMEs' networks: Social capital and the role of intermediaries. European Management Journal, 33(2), 104-115. https://doi. org/10.1016/j.emj.2014.09.003

[23] Kuratko, D. F. (2010). Corporate Entrepreneurship: An Introduction and Research Review. In Handbook of Entrepreneurship Research (pp. 129-163). https://doi.org/10.1007/978-1-4419-1191-9_6

[24] Ling, Y., Wei, L., Klimoski, R. J., \& Wu, L. (2015). Benefiting from CEO's empowerment of TMTs: Does CEO-TMT dissimilarity matter? Leadership Quarterly, 26(6), 1066-1079. https://doi.org/10.1016/ j.leaqua.2015.07.006

[25] Lyver, M. J., \& Lu, T. J. (2018). Sustaining innovation performance in SMEs: Exploring the roles of strategic entrepreneurship and IT capabilities. Sustainability (Switzerland). https://doi.org/10.3390/su 10020442

[26] Majeed, S. (2011). The Impact of Competitive Advantage on Organizational Performance. European Journal of Business and Management, 3(4), 191-197. https://doi.org/10.1016/j.accinf.2006.12.001

[27] McAdam, R., Moffett, S., Hazlett, S. A., \& Shevlin, M. (2010). Developing a model of innovation implementation for UK SMEs: A path analysis and explanatory case analysis. International Small Business Journal, 28(3), 195-214. https://doi.org/10.1177/0266242609360610

[28] Newsted, C. \&. (1999). Structural equation modeling analysis with small samples using Partial Least Squares. Thousands Oaks, CA: Sage, R. Hoyle (Statistical Strategies for Small Sample Research), 307-341. 
Digital Capability and Innovation Strategy to Develop the Performance and Competitive Advantages of Fashion Smes in Jakarta, Indonesia

[29] Parida, V., Oghazi, P., \& Cedergren, S. (2016). A study of how ICT capabilities can influence dynamic capabilities. Journal of Enterprise Information Management, 29(2), 179-201. https://doi.org/10.1108/ JEIM-07-2012-0039

[30] Porter, M. E. (2008). Strategy Strategy the Five Competitive. Harvard Business Review, 86(January), 7894. https://doi.org/Article

[31] Porter, M., \& Michal E, P. (2013). Strategy and the Internet - Harvard Business Review. Harvard Business Review, 2011 March(January). Retrieved from http://hbr.org/2001/03/strategy-and-the-internet/ar/1

[32] Qosasi, A., \& Permana, E. (2017). Pemanfaatan wadah berbagi pengetahuan untuk membangun brand aura umkm fashion di jakarta. Prosiding Seminar Nasional Ekonomi Dan Bisnis (SNEBIS), 1(1).

[33] Rai, Patnayakuni, \& Seth. (2006). Firm Performance Impacts of Digitally Enabled Supply Chain Integration Capabilities. MIS Quarterly, 30(2), 225. https://doi.org/10.2307/25148729

[34] Robert Nowacki, M. W. S. (2012). INNOVATION IN THE MANAGEMENT OF SMEs IN THE SERVICE SECTOR. Journal of Economic Literature, XIV(6), 755-773.

[35] Roostika, R., \& Muafi, M. (2014). The Role of Source Credibility and Place Attachment in Enhancing Visitors' Satisfaction. Journal of Technology Management,13(3), 239-252.

[36] Roostika, R., Wahyuningsih, T., \& Haryono, S. (2015). the Impacts of External Competitiveness Factors in the Handicrafts Industry. Wpływ Zewnętrznych Czynników Konkurencyjności W Przemyśle Rzemieślniczym., 12(1), 166-176. Retrieved from http://offcampus.lib.washington.edu/login?url=http:// search.ebscohost.com/login.aspx?direct=true \&db=bth\&AN=116257717\&site=ehost-live

[37] Russell, S. N., \& Millar, H. H. (2014). Exploring the Relationships among Sustainable Manufacturing Practices, Business Performance and Competitive Advantage: Perspectives from a Developing Economy. Journal of Management and Sustainability, 4(3). https://doi.org/10.5539/jms.v4n3p37

[38] Şerbu, R. S., \& Borza, S. (2014). Achieving sustainable competitive advantage of Romanian rural area by integrating information technologies: An interdisciplinary approach. Studies in Informatics and Control, 23(2), 215-222.

[39] Sudaryanto, Ragimun, \& Wijayanti, R. R. (2014). Strategi Pemberdayaan UMKM Menghadapi Pasar Bebas Asean. Www.Kemenkeu.Go.Id, 1-32. Retrieved from http://www.perpustakaan.depkeu.go.id/ FOLDERJURNAL/2014_kajian_pkem_Strategi Pemberdayaan UMKM.pdf.

[40] Suwarno, S. and. (2002). Model Persamaan Structural, Teori dan Aplikasinya. Bogor: IPB Press.

[41] Tarabieh, S.M.Z.A., Ahmad, Z.A. \& Siron, R. (2015). The Synergistic Impact of Customer Orientation and Supplementary Services on Competitive Advantage and Organizational Performance (Pilot Survey). International Review of Management and Business Research, Vol. 1, No, .484- 499.

[42] Tenenhaus, M., \& Esposito, V. (2005). PLS path modeling. Computational Statistics \& Data Analysis, 48, 159-205. https://doi.org/10.1016/j.csda.2004.03.005

Citation: Erwin Permana, et.al. "Digital Capability and Innovation Strategy to Develop the Performance and Competitive Advantages of Fashion Smes in Jakarta, Indonesia" International Journal of Managerial Studies and Research (IJMSR), vol 7, no.11, 2019, pp. 5-15. doi: http://dx.doi.org/10.20431/2349-0349.0711002.

Copyright: (C) 2019 Authors. This is an open-access article distributed under the terms of the Creative Commons Attribution License, which permits unrestricted use, distribution, and reproduction in any medium, provided the original author and source are credited. 